\title{
An Analysis of the Narrative Strategy of Current Chinese Youth Films in the Light of Audiences' Psychological Needs
}

\author{
Yan Jun* \\ School of Foreign Languages, Sichuan University of Science and Engineering, Zigong, China
}

*Corresponding Author: Yan Jun, School of Foreign Languages, Sichuan University of Science and Engineering, Zigong, China

\begin{abstract}
In recent years, quite few of youth films have made good box office performance. With close study it could be revealed that by meticulously choosing the narrator, applying ocularisation and anachronies, presenting sounds and scenes with time features, youth films generally possess narrative strategies which meet the physiological needs of the mainstream audience, especially those audiences born after 1980 and 1990s. That is an important reason for the popularity of youth films. Nevertheless, youth films are harshly criticized for their increasingly stereotyped narrative strategy and it will inevitably make the audience end up in aesthetic weariness. So, to maintain the audience's enthusiasm, youth films should have their narrative pattern diversified, and the focus should be expanded to cover youth of different ages and different types of people. At the end of 2017, the film Youth attracted audiences born in 1950s and 1960s,by setting its background from 1960s to 1980s, although it has not completely jumped out of the narrative pattern of previous youth films. In 2018, Forever Young finally presented a new narrative pattern of the youth film by exploring the meaning of youth in different ages, and so expanded its circle of audience to people of several generations, and realized the transcendency of the narrative strategy of youth films.
\end{abstract}

Keywords: Youth Film; Narrative Strategy, Audience's Psychology

\section{INTRODUCTION}

"The youth film, characterized by young people with distinctive features of youth subculture, reflects life, psychological movements and the spiritual world of people in the transitional period from childhood to adulthood."[1] In the past several years, China's youth films had a blowout phenomenon, and many films have won good box office results. The box offices of The Best The Lost, You Are My Sunshine both exceeded 400 million yuan [2]. The Left Ear, the maiden work of Alec Sue, made a box office over 350 million Yuan after it had been released for a little more than a week. Vicki Zhao's work So Young had a box office more than 700 million Yuan. According to statistics, in 2013 and 2014, youth films' total box office exceeded 4 billion Yuan, becoming one of the most popular film types in Chinese film market at present[3].At the same time, youth films are harshly criticized because of their unified model, extravagant nostalgia, excessive emphasis on love, lack of thought and positive guidance for young people. The soared-high box offices of youth films and their bad reputations form a stark contrast and arouse the concern both of the public and the critics, which could hardly be ignored. Data show that in 2014, films attracted 830 million viewers in China, of which audiences aging of 19 to 30 accounted for more than 50\% [4], which means more than half of the audiences were born after 1980 and 1990. Some of them are experiencing youth; some others are experiencing the loss of it. With close study, it could be revealed that the narrative strategies of youth films which meet the psychological needs of the mainstream audiences is a major reason for the popularity of youth films.

In 2016, the youth film once went silent after the heat of the transition. Although this year did not see eye-catching youth films, judging from the growth and structure of the Chinese film audience, youth films still have a strong market. According to the 2017 China Film Industry Report released on June 19, 2017, the number of people watching Chinese films in 2016 reached 1.372 billion, far exceeding the 466 million in 2012, and China's movie audience in 2016 was still very young, mostly between the ages of 19 and 30, accounting for 75.7 percent. It also pointed out that viewers between 13 and 15 years old or 16 to 18 years old were up 1.2 percent and 5.1 percent over the same period last year, 
while the proportion of viewers aged 51 and older was less than 0.3 percent, accompanied by a continuous reduction of viewers aged over 40. In particular, there were few movies in the market that can attract people over 40 into the cinema. Therefore, the report also pointed out that the Chinese filmmakers should struggle to explore the market of the elderly.

In late 2017, Feng Xiaogang's Youth heralded the return of Nirvana of the youth film in a new mode. Set in the 1970's and 1980s, the film is about love and other experiences of a group of young people in the ideal and passionate military art troupe. After recalling the youth of the late '70s and' 80s, Youth succeeded in winning the audience in the middle and old age by recalling the youth of the 60's. At the end of the film, the song Flos Velvet gushed out of the memory of the 50's, 60's, and even the '70s'. The film once became a hot topic during its releasement. According to China's box-office network, Youth ranked 8th at the box office in 2017. According to Baidu Nuomi.com, as of February 25, 2018, the total box office of Youth has reached 1.422 billion yuan.

In the following early 2018, the film Forever Young directed by Li Fangfang, staring Zhang Ziyi, Huang Xiaoming, Zhang Zhen, Wang Lihong, and Chen Chusheng once again broke the audience's expectations for youth films. It not only tells the youth of a generation, but also shows the youth of several generations. The film covers four different times of the story of youth, and shows four generations of people's adherence to the sincerity of youth in contradictions and struggle. All four stories point to a common theme: good virtue is the foundation of youth, and only by being sincere to yourself, by removing distractions and doubts, can we move forward bravely. By February 25, 2018, the movie had a book office of 758 million in 45 days, according to Baidu's Nuomi Film Network.

From a single plot pattern to a complex plot pattern, from a single narrative to a polyphonic narrative, from simply remembering youth to exploring the significance of life while admiring youth, youth films have been changing increasingly diversified. Youth films are coruscating new vitality under the efforts of numerous filmmakers.

This paper will analyze the narrative strategy of Chinese youth films in recent years from the perspective of narrator, visual focus, narrative time, sound and picture, and reveals how youth films satisfy the audience's psychological needs from the narrative strategy, and sums up the success and failure of the narrative strategy of youth films to contribute to the development of this type of films.

\section{THE NARRATOR IN YOUTH FILMS}

A film tells a story, so it is a narrative. Any narrative has a narrator. But different from a literature work, a film is a double narrative fulfilled by means of sound and picture. That means the narrator of a film makes the audience perceive the story through sounds and pictures in the film, instead of written language. According to the narrators' different roles in films, they can be classified as the "big image master" and the obvious narrator.[5] The "big image master" refers to the integration of various mechanical and technical means in the production of a film, so "the big image master" can intervene and change the perception of the audience. Some theorists also call it the "invisible narrator", "representor" or "hidden narrator", because it hides behind the screen, without being noticed by the audience, and sometimes makes the audience have the illusion that the story takes place by itself without the intervention of narrator. On the contrary, the obvious narrator refers to the visible narrator in the film, who is in the fictional world, sometimes is the protagonist, sometimes is the supporting role. The obvious narrator narrates below the level of the "big image master".

In these years, a double narrative mode is applied in most youth films in China, in which the "big image master" coexists with the obvious narrator. For example, this narrative mode is used in You Are the Apple of My Eye, The Best the Lost, My Old Classmate, The Left Ear, Youth, while in Forever Young, So Young, there is no obvious narrator.

In the double narrative mode, the obvious narrator is usually a character about 30 years old, who is at the end of youth, and recalling his or her youth in his or her memory. The sentimental recollection of beautiful but regrettable youth can easily win emotional identification of the audiences born after 1980. For example, in You Are the Apple of My Eye, the obvious narrator is the male protagonist, who explains, with a first-person off-screen voice, that the story happened in 1994, when he was 16 , while the famous singer Tom was alive, and more than one million cassettes of Jacky Cheung's album Kiss Goodbye were sold. With the audiences hearing those familiar names and seeing those familiar 
items, the beautiful but lost youth emerges from their memories, and their emotional identification with the character is achieved. In My Old Classmate the obvious narrator is also the male protagonist, who is about 30. The film starts with his off-screen narrating, and then, flashes back to the year 1993 through a pair of myopia-treating glasses left by his high school girlfriend. With the flashback, audiences born after 1980seem to be brought back to their high school age. In The Best the Lost, except for the absent female protagonist in the wedding, the other four high school classmates are all obvious narrators, who, in turn, recollect, in the wedding, their high school and college years and complete their recollection of those years together. In their respective memories, they are respectively the protagonist of the story. So the film caters for the psychological demands of different types of audiences, and those audiences can find their own shadows in the film. At the same time, while those leading characters recollect the past slowly sadly and regretfully, a sharp contrast is formed between the sad, sorrowful grown-up characters and their restless, fearless, ignorant young selves in flashbacks, so a nostalgic feeling could not be helped surging up in the mind of the audiences born after 1980. Therefore, the intense identification of the audiences with the characters is obtained.

According to Freud, the sexual impulse in childhood is represented as narcissism. He said, "With a just a little thought, we can see that there is such love for one's own body, so this phenomenon will not be completely exceptional or meaningless. Maybe this kind of narcissism is a universal primitive phenomenon. Only with this phenomenon, did love for the others come into being, but the phenomenon of narcissism does not have to disappear."[6]This is similar to the relationship between the baby and his mirror image. The narrating of the protagonists born after 1980 makes the audiences saw themselves in the film, and attracted by their lost youth in dreamland created by the intermixing of sound and light.

In films without the obvious narrator, the "big image master" can also bring the audiences born after 1980 into the recollection of youth, with different sounds and images. So Young is a film without an obvious narrator. In it, the heroine's dream of being the pea princess makes the female audience remember their dreams of becoming a princess; the green, noisy hard-seat car of the train, the simple, quiet train station, bring the audience back to the days of riding on the train to the University. So those scenes in the beginning of the film arouse the audiences' recollection of youth as well. In the progress of the story, the "big image master" arouses their emotional resonance of audiences born after 1980 with sounds and images typical in 1980s. For instance, the poster of the Joey Wong, the famous actress in 90s is on the wardrobe of the hero in You Are the Apple of My Eye; the song You Are Wind and I Am Sand is heard in the ice rink in The Best The Lost; the song Green Apple Paradiseis on the air while the hero has a fight on the top of the teaching building in My Old Classmate. All of them arouse strong resonance of the audiences born after 1980 .

Targeting main stream audiences born in1970s and 1980s, youth films released from 2013 to 2014 lost audience born in 60s and 50s and could cause audiences' aesthetic fatigue because of the repeated portrayal and remembrance of the youth of this era. Fortunately, at the end of 2017, the release of Youth just made up for this shortcoming.

Although Youth still applied the double narration of the obvious narrator and the big image master, Xiao Suizi, the obvious narrator, has very few voice-over sounds, which makes it difficult for the audience to resonate with her. However, the age-specific images and sounds can create a great sense of identity among the audience familiar with the era, such as the art troupe in the 70s, and its performance full of characteristics of the era. The depiction of such a background can really appeal to older audiences who have similar experiences. Compared with the previous youth film, Youth achieved a breakthrough in the setting of the target audience.

Forever Young applies the perspective of the big image master. Although it loses the identification of the characters brought by the obvious narrator, it allows the narrative of the whole film to intersect in four different times. Every scene and event presented by the big image master is a symbol of these times. Forever Young pursues not only the audience's identification with the characters but also more importantly the theme of the film: the meaning of youth. No doubt, in this respect, Forever Young once again achieved a breakthrough in youth films.

\section{OCULARISATION OF YOUTH FILMS}

Ocularisation of youth films can also cause the resonance of the audiences and promote the 
identification of the audiences with the characters. "Ocularisation represents the relationship between what a camera presents and what is regarded as what a character sees."[7]Inner ocularisation means that the camera is the eyes of a character in the fictional world, so what is presented by the camera is what the character sees. Zero ocularisation means the camera is not the eyes of any character. In that case, the camera belongs to "the big image master". In youth film, inner ocularisation of the obvious narrator, or inner ocularisation of one or two characters, combined with zero ocularisation is usually applied.

Zero ocularisation is mainly used in the description of scenes and the relationship among characters. For example, it is used to describe the freshmen's entering the university in 1999s in So Young, the classroom scene in 1990s and the break of SARS in 2000sin My Old Classmate, the life scenes of the Art Group in Youth, the scenes in the middle schools and hospitals in Forever Young. These scenes not only have a strong sense of youth, but also have the characteristics of the age, which can move the audience who know the age deeply.

In the description of the relationship among characters, zero ocularisation can create suspense, and the suspense is a very effective way to attract and maintain the audience's attention. For instance, in the beginning of So Young, "the big image master" makes the audience see the heroine on one side of the railway station, sitting on her trunk, perplexed and disappointed, and then leave the station alone with the heavy trunk, while on the other side of the station, a young boy hides in a corner and secretly watches the heroine. Here, "the big image master" creates suspense to attract the audience, which lasts to the middle of the film, so the audience's attention is maintained to that moment. In The Left Ear, "the big image master" enables the audience to see the heroine work hard to support the boy she loves, take care of him, and encourage him, so the audience is eager to know whether they can end up together. In My Old Classmate, when the audience sees the hero receiving the wedding invitation from the heroine, he or she cannot help finding out their relation, and when the puzzle is resolved with the hero's recollection, the audience wants to know why they are not together. The biggest suspense of Forever Young is what seems to be a loose connection between the four stories. As the stories unfold, the audience finds the answer at the end of the film and at the same time understands the theme of the film.

Inner ocularisation presents what the character sees and serves to revels the psychological movement of the character, while zero ocularisation adds details to the plot and shows the background of the story. For example, in So Young, while the heroine enters the hero's dorm, zero ocularisation is replaced by inner ocularisation of the heroine to display the untidiness of the dorm the heroine sees, and this scene can make female audiences recall what they saw the moment they entered boys' dorm for the first time. Then, as the heroine lifts the curtain of the bed, shocked by the tidy bed of the hero, the audience experiences the same complex feeling of surprise, curiosity and admiration as the heroin experiences. In this way, the heroin's sudden affection for the hero and her persisting and pure love afterwards, become so understandable and moving to the audience.

In The Best The Lost, when the hero comes back to the classroom, the heroin is writing on the blackboard. At that moment, zero ocularisation is replaced by inner ocularisation of the hero. From his eyes, the audience sees the heroin's beautiful figure in white shirt and blue dress while the bright sunshine going through the window, and so, feels strongly the hero's arising affection for the heroin. Similar shifting of ocularisation exists in My Old Classmate. When the young heroin takes off the myopia-treating glasses, zero ocularisation shifts to inner ocularisation of the hero. From the eyes of the hero, the audience sees the heroin's sweet smile, and recalls their first meeting with his or her young lover. By transferring zero ocularization to inner ocularisation of the character the resonance of the audience is intensified.

In Youth, when Liu Feng returns to his dormitory after the art troupe is dismissed, the film changes from zero ocularisation to Liu Feng's inner ocularisation. He founds a loose floor plan, under which he finds Xiaoping's hidden military uniform photos. From Liu Feng's angle of view, we feel his surprise and regret, and this paves the way for their reunion. In the same way, when a truck of wounded is brought down on the defensive counter-attack field against Vietnam, the film changes from zero ocularisation to The Xiaoping's inner ocularisation. When the truck is opened, the audience see the startling scene from her perspective to feel the deeply the cruelty of the war, in contrast with beauty of youth. 
In Forever Young there is also inner oculrisation. For example, the scene before Shen Guangyao's last air battle sacrifice is presented from Shen Guangyao's inner ocularisation; the scene in which Lin Guoguo draws on the window glass and looks back at the quadruplets is presented from Lin Guoguo's inner ocularisation; the description of Wu Linglan's participation in Tagore's speech is Wu Linglan's inner ocularisation... The inner ocularisation of these characters shows the inner activities of the characters and serves the theme of the film - unrepentant youth is achieved through following one's own choice without query.

\section{NARRATIVE TIME OF THE YOUTH FILM}

There are two kinds of narrative time: the time of the story and the time of the narration. The relationship between these two kinds of time can be described with "the temporal sequence", "the duration" and "the frequency".

\subsection{The Temporal Order in Youth Films}

The temporal sequence refers to the sequence of the story in the narration. The discordance between the sequence of story and the sequence of narration is called the an achrony. [8] There are two big categories of an achronies: prolepsis and analepsis. Prolepsis is any "narrative maneuver that consists of narrating, or evoking in advance, an event that will take place later" [8]. Analepsis is any "evocation after the fact of an event that took place earlier than the point in the story where we are at any given moment"[8]. For example, in You Are the Apple of My Eye, My Old Classmate, So Young, after the main characters' present situation is briefly described, the analepsis of their youth begins as the obvious narrator's, also the main character's voiceover cut in. In You Are the Apple of My Eye, as the camera is shifted from the hero in the wedding to the hero in high school, the analepsis begins with voiceover cutting in. In My Old Classmate, and So Young, the anlepsis begins as the scene shifts from the present to the past. In You Are the Apple of My Eye and My Old Classmate, the analepsis lasts almost to the end of the film and then the narration returns to the present and continues the story cut off at the beginning of the film by the analepsis.

This kind of analepsis can often create suspense to attract and maintain the attention of the audience. For instance, in the beginning of You Are the Apple of My Eye, the hero stands by the window in a tuxedo, and his friends urge him to hurry up, so not to keep the bride waiting, but at that moment, the film flashes back to the high school period of the hero, without revealing whether the hero is the bridegroom of not. The suspense is kept until the end of the film. In this way, the attention of the audience is maintained during the whole analepsis. Then at the end when the audience find out that the hero is not the bridegroom, with the entire story revealed, the audience cannot help having sympathy for the hero and lamenting from the hero's angle that "My girlfriend is getting married, but the bridegroom is not me!" In So Young, the hero declaims in the beginning of the film that he left aside a 13 scores question in his college entrance exam for a girl, but they do not end together. However, the reason is not revealed and the analepsis begins, so the audience has to find out the reason in the analepsis with the suspense in mind.

At the same time, the analepsis not only shows youth in the past, but also evokes pity and regret for youth of the audience with the contrast of the past and the present, and makes people lament the unpredictability and dissatisfaction of life. In So Young, the main characters recall the past in turn. As obvious narrators, they bemoan their impulse, fearlessness and ignorance in their youth. For example, while the character Zhao Ye recalls his first love, on the sunny background on the beach, a group of young people are playing happily, but by contrast, the voiceover of the grown up Zhao Ye sighs, "My first love is just a joke, because when I fell in love with a girl for the first time in my life, she just fell in love with someone else." For another example, in recollection that the several high school friends have a farewell meeting in a food stall as the Chinese food ball team plays against Brazilian football team, the voiceover of grown-up Lin Jiamo laments: "In that year, Joe was back. He just made for the football game China against Brazil at the world cup. It is funny that I felt we were just like the Chinese team: before the crushing defeat, we were so optimistic to believe that we could change the fate. Afterwards, facing the wreckage, I can just say, at least we have tried." Those analepses with voiceover can easily cause the audience's lament and regret for youth.

In Youth, although the story is introduced in the beginning of the film by Xiao Yu-zi's voice-over voice, the whole film is still carried out in chronological order. In Forever Young, although all four 
narrative lines are carried out in chronological order, their cross connections in characters and places make them prolepses and analepses of each other. These special prolepses and analepses not only create suspense and maintain the attention of the audience, but also make the audience admire the equally brilliant youth in different time and space. This is also a great breakthrough in time setting.

\subsection{Narrative Movements in Youth Films}

According to Genette, there are four narrative movements: descriptive pause, scene, summary and ellipsis. [8]Descriptive pause refers to some section of narrative discourse corresponding to nonexistent diegetic duration. Scene realizes conventionally the equality of time between narrative and story, while summary is narration in few paragraphs or a few pages of several days, months, or years of existence, without details or action or speech. Ellipsis refers to a nonexistent section of narrative corresponding to some duration of story. Because of the diachronic nature of the film, descriptive pause is scarcely used in the youth film. Scene, summary and ellipsis are mainly applied. Scene is mainly used to promote the development of the story, and to describe the important occasions rich in color of youth, such as the enrollment, graduation, encounter, emotional crisis, breaking up of the main characters. For example, scene is used to present the heroine's graduation speech, the hero's heroic deed to substitute the heroine to get punished in You Are the Apple of My Eye, and the enrollment, the encounter of the hero and heroine in So Young. At the same time, summary or ellipsis is used to present those unimportant events. For instance, in So Young, there are only several shots of class teaching and two shots of self learning. The shots of class teaching are confined to the description of the heroine's being late for class, and the shots of self learning are just used to reveal the emotional entanglement of the hero and heroine. The process of studying is reduced to few very brief sketches in the whole film.

In My Old Classmate, the hero's struggle to get into the art class is summarized by one sentence of the hero's voice over: "In 1996, as a result of my hard work, I was transferred into the art class." In So Young, The Left Ear, You Are the Apple of My Eye, the process of learning is also largely omitted. Consequently, some audience wonder, "Do these kids need to study? It seems that they just deal with their romantic relationship." This query is not unreasonable, but viewing from the narration of the film, the ellipsis or abbreviation of the learning process is just a narrative strategy of the film.

As statics reveal, "the average age of the mainstream movie audience in China dropped from 25.7 in 2009 to 21.4."[9]As we can see, most audiences are people who are experiencing youth. In the growth of them, learning takes most time of their life. For those teenage high school students, romantic relationship is a taboo, and for college students in the early 20 it is a fresh experience. They are full of confusion and curiosity because of love, while they have experienced and done too much of learning. Therefore, no matter it is a taboo or a fresh experience, the love story of youth film meets their yearning for and curiosity of love. Therefore, those born after 1990have become the mainstream of audience. As for those born after 1980 and have experienced youth, campus love is the sweetest and most sentimental memory of their youth. Furth more, love is an eternal topic of human beings. Consequently, love has become an important theme in the current youth films. In the description of love relationships, the filmmakers usually use descriptive pause and scene to narrate, while summary and ellipsis are used to narrate other parts of the plot.

The scenes in Youth mainly focus on revealing of the beauty of youth and the cruelty of war, such as the rehearsal of the art troupe at the beginning of the film, the gathering before the dismiss of the art group, Liu Feng's team's being ambushed. The former evokes memories of youth by the audience who have experienced it, while the latter makes them lament misfortune in youth. In the second half of the film, He Xiaoping's solo dance is a combination of beauty and misfortune of youth, which makes the audience sob. The scenes in Forever Young mainly focus on scenes related to the theme and the fate of the characters, such as Tagore's speech at Tsinghua University, teachers and students of Southwest Union University insisting on their study under air strikes, and Wang Minjia being abused. Since the four stories span nearly 100 years, the other plots are largely omitted and summarized.

\section{SOUND AND PICTURE OF THE YOUTH FILM}

ZhangYimou, the famous director, once said, "As a mass artistic and entertainment form, the film cannot but give in to social and cultural customs, collective preferences and the great pressure from 
the audience's ingrained habits of appreciation."'[10]So similar elements are found in different youth films: white shirts and blue skirts, green trees and bright sun shine, old popular songs, beautiful and young faces, and so on, because these sounds and pictures are the most beautiful and wonderful things about youth in the memories of people born in 1980s, 1990s and even 1970s.In the first half of Youth, the life of the art troupe is presented through the yellow filter to with songs from the 1970s to make all the things seem under sun shine. Although some audiences think that this kind of warm and serene filter is not suitable to express the contradiction of the art troupe itself, and is quite obtrusive contrasted with the bitter war in the latter part, it resonates most people's memory of youth which is as beautiful and bright as sunshine. It can be seen although Youth describes the youth of people in different age; it fails to extricate itself from the plot pattern of depicting the most beautiful youth in memory.

Forever Young is a breakthrough of the youth film on the setting of scenes and sound. It is not blindly nostalgic, but focused on revealing of the theme. This is partly because the film spans four periods, and no one in the audience has experienced the first two decades of the twentieth century, and the last period is what everyone is experiencing. So, the only part that can evoke the nostalgia of the audience is the part of the $1960 \mathrm{~s}$. However, the theme of the film is not nostalgia, but the transmission of the theme, so the portray 60's severs the revelation of the theme, rather than blind beautification of the age. For example, streets covered with ginkgo leaves, sunny dispensaries and beautiful nurses in hospitals pictures contrasts sharply with Wang Minjia's tragic experiences, setting off the impermanence of fate and the fortitude of love. The only song in the film is Fantastic Grace. Although this song is not familiar to after 60s, and cannot arouse their nostalgia, it fits with the theme. The song appears twice in the film. One time, in the 1930s, a foreign missionary, who might have lost his legs in the war, with a group of orphans, relies on the song Fantastic Grace to disperse hunger, hoping for "good luck" in the heavy rain. It is clear that "fantastic grace" of the war comes not only from the air force soldier who brings them food, but also from the brave missionary who crossed the border to support these orphans and fosters heroes like Chen Peng. The song carries on again when Wang Minjia is taken by Chen Peng to his birth place in the 1960s, where she is accepted by local villagers. It is not only an echo of that song in the 1930s, but also a revelation of theme of the film: establishing virtue, setting doctrines without doubts and distractions, and this spirit is passed on from generation to generation. Therefore, although this song is not a familiar song to the audience, it is in line with the tragedy and forbearance presented in the film. The characters' strength, tolerance and kindness make the audience all tears.

\section{CONCLUSION}

To sum up, the current well acceptance of the youth film is largely because the film's narrative strategy meets the psychological needs of the mainstream audience. Nevertheless, the increasingly stereotyped narrative strategy and plots will inevitably make the audience end up in aesthetic weariness after a period of aesthetic excitement, and at last loss their interest in the youth film. So, to maintain the audience's enthusiasm in this type of films, the profound meaning and unique features of youth of different ages should be excavated. Youth, released at the end of 2017, has made a breakthrough in the plot of the story and the setting of the target audience, although it has not completely jumped out of the narrative pattern of previous youth films. It not only attracts the audience born in 1960s, but also exposes some social problems while remembering the past youth. In 2018, Forever Young completely extracted itself from the pattern of previous youth films of blindly remembering youth, by exploring the meaning of youth in different ages, so realized the sublimation and transcendence of youth films.

\section{REFERENCES}

[1] Wu Qian. The Youth's Story in the Movie: the Comparison Study on Youth Movie for Both Straights Since the New Millennium[D].Southwest University.2013.

[2] Chen Junyu. When Do Domestic Youth Films Become Mature? [N]. Workers' Daily : July 20th, 2015.

[3] Lu Dinggong. There Should be More Than One Mode of Youth [N] .Guangming Daily : May 9th 2015.

[4] Chen Junyu. When Do Domestic Youth Films Become Mature? [N]. Workers' Daily : July 20th, 2015.

[5] André Gaudreault, Franecois Jost. What is Film Naratology? [M]. Beijing : The Commercial Press.2015, pp59. 
An Analysis of the Narrative Strategy of Current Chinese Youth Films in the Light of Audiences' Psychological Needs

[6] André Gaudreault, FranecoisJost. What is Film Naratology?[M]. Beijing : The Commercial Press.2015,pp177.

[7] Genette, Gerad..Narrative Discourse[M]. (Jane E. Lewin. Trans.). Oxford: Basil Blackwell,1980,p40, p49, p85.

[8] The audience is getting younger and younger, and the film is catching the eye. [N].Liberation Daily http://www.ce.cn/culture/gd/201407/23/t20140723_3214185.shtmlJuly 23th, 2014, 13:07.

[9] Zhang Yimou and The Story of Qiuju [N].Beijing Youth Daily. August 1irst, 1992.

\section{AUTHOR'S BIOGRAPHY}

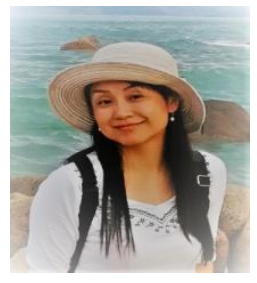

Yan Jun, was born in 1975, an associate professor in the foreign language school of Sichuan University of Science \&Engineering, in Zigong, Sichuan, China, whose research is mainly in Literature and English teaching.

Citation: Yan Jun. "An Analysis of the Narrative Strategy of Current Chinese Youth Films in the Light of Audiences' Psychological Needs " International Journal of Humanities Social Sciences and Education (IJHSSE), vol 5, no. 11, 2018, pp. 8-15. doi: http://dx.doi.org/10.20431/2349-0381.0511002.

Copyright: (C) 2018 Authors. This is an open-access article distributed under the terms of the Creative Commons Attribution License, which permits unrestricted use, distribution, and reproduction in any medium, provided the original author and source are credited. 